If an electronic copy is developed, would you still want to receive a printed issue ?

Yes $(82 \%)$ or No (14\%) $4 \%$ undecided

4

Are you willing to pay an additional US $\$ 5$ or the equivalent in pounds or Dutch guildeıs per year to have access to a complete electronic issue via password?

Yes $(40 \%)$ or No $(56 \%) 4 \%$ undecided

5

Is your main interest in the ICCA Journal (responses not mutually exclusive)

Research (67\%)

Leisure $(41 \%)$

Other $(0 \%)$

End of survey

A large amount of comments and Ideas were received We provide three of them

"Sometımes hardcopıes of the Journal (in its red colour) help to convince sponsors "

"In principle, I am all in favour However, I would urge a degiee of cautıon For example, one advantage of a paper copy is that I can point to a publication and say to colleagues "look, that is my papei and it is in a proper, respectable academic publication", I think that currently they would be rather sceptical of a publication which appeared only or primarily in electronic form

"Electronic publıshing is just around the corner Some journals already do it Let us be leadeis rather than followers

So tar we conclude that our members highly appreciate a printed issue of the ICCA Journal It seems that an electronic copy will not replace the ICCA Journal in its current form in the near future

If you were not among the members reached for this survey, your opınıon is still impoitant to us We invite you to send your comments on this issue to Professor H J van den Herık, Editor-in-Chief ICCA Journal, Unıversiteit Maastricht, Department of Computer Science, PO Box 616, 6200 MD Maastricht, e-mall 1cca@cs unımaas nl

In the June issue we will inform you further on this topic

\title{
CORRESPONDENCE
}

\section{COMPUTER CHESS: A UNIFYING THEME}

\author{
$M$ Levene $^{1}$ \\ London, England
}

In a recent issue the Editors of the ICCA Journal solicited opınions on the future of the Journal As an avid reader of the Journal and a contributor I would like to volce some of my thoughts

I thınk the ICCA is an excellent jouınal of high quality and I am always eagerly looking torwaid to receiving the next issue Personally I do not think that the game of Chess will be 'solved', even when a chess machıne is able to beat the World Champion, an eventuality that now seems to be unquestionable There are still many avenues to explore in heuristics of game playıng that will improve the quality of decision making of current algorithms I teel that in this respect the ICCA Journal needs to detine cleally its aims and scope Looking through the current issue I did not see any such statement, although it is clearly stated that the ICCA's purpose is to promote and further all aspects of computer chess

I Department of Computer Science, Unıversity College London, Gower Street, London, WC1E 6BT, England Ema11 M Levene@cs ucl ac uk 
I find it interesting to note that the ICCA Journal has published many artıcles whose main theme is not computer chess, but relate to general aspects of game playing, especially heuristic searching methods I thınk the ICCA Journal should acknowledge in its arms and scope that there are various problems relating to heurıstic game playing that can be addressed through strategic games other than Chess I will briefly list some such games and problems

The game of Go is an example where the 'brute-force' method, which has been so successful in Chess, does not seem to work Makıng progress in artificial Go demands heurıstic searching technıques that are much more selectıve than current methods and a much better understanding of how to encode knowledge, which may be local to independent parts of the game tree The game of Bridge is an example of a game with imperfect information, as opposed to Chess in which the information is perfect Again, new heuristic search methods need to be developed and explored to take into account the numerous eventualities The game of Backgammon is an example of a game with chance moves, as opposed to Chess which has no chance element Although strong programs have recently been developed using temporal differencing techniques, there is still the open problem of developing novel search methods for such games Finally, Diplomacy is an example of a game with $\mathrm{N}$ players, where $\mathrm{N}$ is greater than two, as opposed to Chess where there are only two players Such games pose a variety of new challenges such as modelling the negotiation between players and searching $\mathrm{N}$-person game trees with large branching factors whose evaluation function is not, in general, zero-sum Here mathematical game theory may prove to have a considerable impact on the direction taken by researchers

I still thınk that computer chess is a unifying theme for a large number of problems in this area and as such I would not like to see the ICCA Journal change its name In addition, Chess provides a central example of what we should aim at with respect to other games I strongly feel that in order to keep abreast with new developments and challenges, and also encourage new research in the area of heuristic game playing, the ICCA should broaden its aims and scope to include other strategic games apart from Chess

\title{
ICCA TOURNAMENT RULES REVISITED
}

\author{
Ernst A Helnz' \\ Karlsruhe, Germany
}

Dear ICCA Board and Fellow ICCA Members,

Since my first participation in an ICCA tournament (as member of the DARKTHOUGHT team during the $8^{\text {th }}$ WCCC in Hong Kong, 1995) I have had the same mixed feelıngs about the definitions of "amateur vs professional' as anybody else Therefore, I sent an initial proposal to David Levy on July 31, 1995, intıoducing "pure" and "semı" subcategories for both amateurs and professionals Unfortunately, nothing ever came thereof although the proposal surely had some merts

Right now, however, tımes have changed and so has my opınion as for the dreaded "amateur vs professıonal" case Moreover, anotheı important issue has emerged - namely "kıller book lines bustıng commercial programs " Because any live tournament will be very limited in its possible number of rounds, I personally teel this issue to be of great importance in order to ensure future participation of commercial programs in ICCA events

In the following, I propose new solutions to both of the above while hopıng for your comments and fruttul discussions 1

\footnotetext{
1 School of Computer Science (IPD), University of Karlsruhe, P O Box 6980, D-76128 Karlsruhe, Germany Ema1l heinze@1ra uka de
} 